\begin{tabular}{|c|c|}
\hline Title & The lacustrine section at Lukundol, Kathmandu basin, Nepal: Dating and magnetic fabric aspects \\
\hline Author(s) & Goddu, Srinivasa Rao; A ppel, Erwin; Gautam, Pitambar; Oches, Eric A .; Wehland, Florian \\
\hline Citation & $\begin{array}{l}\text { Journal of A sian Earth Sciences, 30(1), } 73-81 \\
\text { https://doi.org/10.1016/.jseaes.2006.07.009 }\end{array}$ \\
\hline Issue Date & 2007-04-01 \\
\hline Doc URL & http:/hdl.handle.net/2115/68302 \\
\hline Rights & $\begin{array}{l}\text { (0) 2007. This manuscript version is made available under the CC-BY-NC-ND } 4.0 \text { license } \\
\text { http://creativecommons.org/icenses/by-nc-nd/4.0/ }\end{array}$ \\
\hline Rights(URL) & https://creativecommons.org/icenses/by-nc-nd/4.0/ \\
\hline Type & article (author version) \\
\hline File Information & j.jseaes.2006.07.009.pdf \\
\hline
\end{tabular}

Instructions for use 


\title{
The Lacustrine Section at Lukundol, Kathmandu Basin, Nepal: Dating and Palaeoenvironmental Aspects
}

\author{
Srinivasa Rao Goddu ${ }^{1}$, Erwin Appel ${ }^{1}$, Pitambar Gautam ${ }^{2}$, Eric A. Oches ${ }^{3}$, Florian Wehland ${ }^{1}$ \\ ${ }^{1}$ Institute for Geosciences, University of Tübingen, Sigwartstr. 10, 72076 Tübingen, Germany \\ ${ }^{2}$ Central Department of Geology, Tribhuvan University, Kathmandu, Nepal \\ (now at: COE for Neo-science of Natural History, N222, Faculty of Science, Hokkaido University, N10 \\ W8 Sapporo 060-0810, Japan) \\ ${ }^{3}$ Department of Geology, University of South Florida 4202 E. Fowler Ave. - SCA 528
}

Corresponding author:

Srinivasa Rao GODDU
Institut für Geowissenschaften, Universität Tübingen,
Sigwartstrasse 10
72076 Tübingen, Germany
Email: srinivasa.rao@uni-tuebingen.de
Fax: \#49-(0)7071-295842
Phone: \#49-(0)7071-2974698

\section{Abstract:}

The fluvial and lacustrine sediments of Kathmandu basin in central Nepal are a good archive to study the past environmental changes and the history of development of the SW Indian monsoon. A sequence of about $170 \mathrm{~m}$ exposed at the southern part of the basin is divided into two lithological units: Lukundol Formation and Itaiti Formation. The Lukundol Formation mainly comprises fine-grained sediments whereas gravel beds dominate the Itaiti Formation. In total 750 oriented samples were collected all along the accessible part of the sequence in $10 \mathrm{~cm}^{3}$ plastic boxes with a sampling interval of $\sim 10$ $\mathrm{cm}$. Additional 128 samples were collected for pollen analysis with a sampling interval of $\sim 50 \mathrm{~cm}$. Magnetostratigraphy is established based on four magnetic transitions indicating that the sampled section spans 0.75 to $1.1 \mathrm{Ma}$. Amino-acid dating on a fossil found in a lignite layer at $88 \mathrm{~m}$ yields an age of $\sim 0.8-1.0 \mathrm{Ma}$ is consistent with the age derived from magnetic polarity stratigraphy. Anisotropy of magnetic susceptibility (AMS) measured in 250 samples spanning the whole section reveals a sedimentary fabric, with NW-SE oriented maximum directions. Lithological changes are significant at $67.5 \mathrm{~m}$, above which thick gravel beds appear and imply significant change in the depositional regime. Mainly two magnetic components are identified: Magnetite - dominant all along the whole sequence, and hematite - relatively more important at depths with lower susceptibility. 
Key words: magnetostratigraphy, Cobb Mountain, lacustrine sediments, anisotropy of magnetic susceptibility

\section{Introduction}

It is in general accepted that the dramatic rise of the Tibetan plateau has changed the Indian monsoonal system, thus triggering changes in global climate (Hahn and Manabe, 1975; Raymo and Ruddiman, 1992). To understand the changes in past climate, it is necessary to have long and continuous in time sequences of sediments that serve as records of the past phenomena. It is well-known fact that lacustrine sediments are quite sensitive to both, regional as well as global climatic changes. This study deals with the Kathmandu basin, which is largely influenced by the SW Indian monsoon system and the tectonic activity of Himalayas. It was aimed at establishing an age frame for the Kathmandu basin sediments by applying magnetostratigraphy and amino-acid dating, and furthermore at using magnetic (e.g., susceptibility, artificially imparted remanences and anisotropy of magnetic susceptibility (AMS) and non-magnetic (e.g., total carbonate content, fossil pollen, grain size) parameters to identify general environmental changes within this region. In this paper we present the results of magnetostratigraphy, amino acid dating and anisotropy of magnetic susceptibility. Earlier magnetostratographic study (Yoshida and Gautam, 1988) was carried out on the same section, however with lower resolution.

\section{Geological setting and sampling}

Kathmandu valley in central Nepal is one of the largest intermontane basins in the Lesser Himalayas with an average altitude of $1400 \mathrm{~m}$ above sea level. The basin measures $\sim 25 \mathrm{~km}$ NS and $\sim 30 \mathrm{~km}$ EW covering an area of $\sim 650 \mathrm{~km}^{2}$. It is flanked by mountain ranges of $\sim 2500 \mathrm{~m}$ altitude. Bagmati river, that probably was largely responsible for the basin-fill sediments, is the trunk river that cuts the Mahabharat range and drains southward into the Terai lowland that forms a part of the Gangetic plain (Fig. 1a).

The northern slope of the Kathmandu basin is mainly composed of gneiss and granite, called the Shivapuri Injection Complex, while the rocks of the Phulchauki Group comprising the Tethys Himalayan rocks of Palaeozoic age outcrop in the NW part of the 
Final manuscript of paper published as: Journal of Asian Earth Sciences 30 (2007) 73-81 https://doi.org/10.1016/j.jseaes.2006.07.009

valley. The southern part of the basin is composed of the schists and marbles of the Bhimphedi Group, which is overlain by the Phulchauki Group. Figure 1a,b shows a simplified geological map and cross-section of the Kathmandu basin and location of the sampled section. The maximum thickness of the basin-fill sediments was estimated to be up to $650 \mathrm{~m}$ based on gravity data (Moribayashi and Maruo, 1980). The expected time span of sedimentation is mid-Pliocene to Pleistocene.

The inconsistency in the usage of the formation names by earlier researchers whose studies were limited mainly to the surface exposures has given rise to confusion in the stratigraphic division of the lacustrine, fluvial and deltaic deposits. Sakai (2001) published a proposal for a new stratigraphic scheme based on observations of drilled cores and slimes from boreholes at different locations in the basin and suggested correlation with the existing lithostratigraphic schemes (Table 1).

In this study, a sedimentary section of about $120 \mathrm{~m}$ in thickness from around the Lukundol village in the southern part of the basin was sampled. According to the new stratigraphic division, the present section belongs to the Lukundol Formation and Itaiti Formation (Table 1). The topmost ca. $70 \mathrm{~m}$ section made up of gravel and debris, of the Itaiti Formation, was not sampled due to accessibility problems. Lithology of the sampled section is shown in Figure 2a. The Lukundol Formation at the base of the section is mostly composed of mud, silty clay, clay beds intercalating with lignite beds and a few sand beds. The Itaiti Formation at the upper part comprises fining upward sequences of gravel, fine sand and silty clay with carbonaceous mud. Samples for magnetic studies were taken after removing ca. $2 \mathrm{~cm}$ thick weathered layer at the exposed face using a pick axe. A total of 750 oriented samples were collected in $10 \mathrm{~cm}^{3}$ plastic boxes, maintaining an interval of $10 \mathrm{~cm}$ in fine-grained segments, using a hand-made corer. Additionally, 128 samples (each weighing several grams) were taken for pollen analysis with an interval of $50 \mathrm{~cm}$. Joint analysis of rockmagnetic parameters and pollen data is currently in progress and the results will be described separately.

\section{Magnetostratigraphic and Amino-acid dating}

\subsection{Magnetic minerals and magnetostratigraphy}

In sediments the primary remanence is acquired by alignment of ferro(i)magnetic particles in the ambient magnetic field during or shortly after the deposition and it is termed as depositional (DRM) or post depositional remanent magnetization (pDRM). The recording is efficient in calm depositional environment particularly in fine-grained 
Final manuscript of paper published as: Journal of Asian Earth Sciences 30 (2007) 73-81 https://doi.org/10.1016/j.jseaes.2006.07.009

homogenous sediments. However the exact mechanism of remanence acquisition process is not completely understood (Kent, 1973; Verosub and Banerjee, 1977). Resolving the primary syndepositional remanence along a sedimentary sequence is a fundamental requirement for magnetostratigraphy. Recording is dependent on magnetic mineralogy, magnetic grain size and concentration of the magnetic minerals.

Low temperature susceptibility measurements were done on selected samples using a KLY-3 Kappabridge and a CS-3 temperature unit. Verwey transition and the isotropic point of magnetocrystalline anisotropy are observed in some samples (Fig. 3a) indicating the presence of multidomain magnetite, which is likely of detrital origin. Hightemperature susceptibility measurements were carried out on a few raw samples in argon atmosphere up to $700{ }^{\circ} \mathrm{C}$. All curves show a transformation to magnetite during heating starting at around $300{ }^{\circ} \mathrm{C}$, and are not indicative for the initial magnetic mineralogy (Fig. $3 b)$.

A total of 64 samples were chosen for isothermal remanent magnetization (IRM) acquisition experiments using a MMPM9 pulse magnetizer. For the majority of the samples $>90 \%$ of the saturation is acquired around $250-350 \mathrm{mT}$ and nearly complete saturation is reached at about 550-700 $\mathrm{mT}$ (Fig. 3c). Backfield demagnetization reveals remanence coercive forces (Hcr) between 35-60 mT for most samples (Fig. 3c). Some samples which have relatively lower NRM and low-field mass-specific susceptibility $(\chi)$ acquire saturation magnetization at $>1 \mathrm{~T}$ and have relatively high Hcr values.

After IRM acquisition, a set of samples showing higher and lower susceptibilities were selected for thermal demagnetization experiments using a MMTM18 furnace. The results show that the samples have a mixture of magnetic minerals (Fig. 3d). Most samples contain magnetite and some hematite characterized by maximum unblocking temperatures of $\sim 580^{\circ} \mathrm{C}$ and $\sim 680^{\circ} \mathrm{C}$, respectively (Fig. 3b) but their concentrations differ. Samples with lower $\chi$ show a relatively large contribution of hematite. A significant decrease in magnetization is observed between 300 and $400^{\circ} \mathrm{C}$ for most samples indicating the presence of maghemite. Iron sulfides cannot be excluded as they may contribute to the drop of intensity near $300^{\circ} \mathrm{C}$. AF demagnetization of NRM gave strong indications for acquisition of a gyromagnetic remanence (GRM) in 8 samples probably resting in greigite (Hu et al., 2002).

A few samples were subjected to ARM acquisition (at maximum AF field of 100 $\mathrm{mT}$ with biasing DC field of $0.1 \mathrm{mT}$ using a $2 \mathrm{G} 615$ demagnetizer). After acquisition of 
Final manuscript of paper published as: Journal of Asian Earth Sciences 30 (2007) 73-81 https://doi.org/10.1016/j.jseaes.2006.07.009

ARM along an axis, the samples were stepwise AF demagnetized along the same axis. Joint analysis of the acquisition and demagnetization behaviour suggests two distinct groups of samples predominated respectively by: (i) a relatively soft component with an intersection point at around $25 \mathrm{mT}$; and (ii) a harder component with an intersection point at $55-60 \mathrm{mT}$ (Fig. 3e). Mean $\chi$ is $30.4 \times 10^{-8} \mathrm{~m}^{3} / \mathrm{kg}$ for the lower coercive component and $8.7 \times 10^{-8} \mathrm{~m}^{3} / \mathrm{kg}$ for the higher coercive component.

Magnetic extracts were prepared from few samples and XRD analysis was performed with a Philips Bragg-Brentano diffractometer equipped with a secondary monochromator. The results show only Magnetite among the magnetic mineral present (Fig. 3f). The reason might be that predominantly magnetite was extracted, whereas the other magnetic minerals remained below the detection limit. Maghemite could be also undistinguishable from magnetite when Fe is partially substituted.

Remanent magnetization was measured using a 2G RF SQUID magnetometer equipped with a degausser. About $40 \%$ of all samples showed weak NRM intensities close to the noise level of the magnetometer and could not be used for demagnetization. Three hundred and fifty samples with relatively stronger NRM (in 60\% of the whole quantity) were selected for AF demagnetization covering all horizons along the sequence. About 160 samples could not be used for determination of the characteristic remanent magnetization (ChRM) due to erratic demagnetization behaviour.

Most of the samples show the presence of two components (Fig. 4). A softer component was removed at around 10-15 mT probably of viscous origin, acquired mostly in the present field (Fig. 5a). The soft component may be carried by coarser grained magnetite or maghemite? The second component is quite stable and is considered to represent the ChRM. In most samples the ChRM is directed towards the origin. NRM is reduced to less than $\sim 10 \%$ at an $\mathrm{AF}$ field of $70 \mathrm{mT}$ and $\sim 5 \%$ at $>100 \mathrm{mT}$. At peak $\mathrm{AF}$ fields above $100 \mathrm{mT}$, most of the samples showed unstable behaviour. The directions of the ChRM were determined by principal component analysis. Normal and reverse polarity directions derived from AF demagnetization are not antiparallel (Fig. 5b) indicating that the components could not be completely separated. Nevertheless, polarities can be distinguished.

In Figure 5c the ChRM declinations and inclinations are plotted against their stratigraphic position. Remanence directions were not corrected for bedding as the layers are dipping gently $\left(\sim 5-10^{\circ}\right)$ towards north. A systematic change in polarity transition is 
Final manuscript of paper published as: Journal of Asian Earth Sciences 30 (2007) 73-81 https://doi.org/10.1016/j.jseaes.2006.07.009

observed along the depth, which strongly suggests that the obtained ChRM is a (p)DRM. Four magnetic transitions were observed in the polarity sequence (Fig. 5). The preferred interpretation of them, from top to bottom, is in terms of Brunhes/Matuyama boundary $(6.5 \mathrm{~m})$, upper and lower boundaries of the Jaramillo subchron $(77.5 \mathrm{~m}$ and $104.5 \mathrm{~m})$ and probably the upper boundary of the Cobb Mountain polarity event $(119.5 \mathrm{~m})$. An alternative interpretation for the lowermost normal polarity zone is in terms of the Olduvai subchron.

In transition zones the sequence of normal and reverse polarities is not consistent which indicates that the data inherit lock-in depth problems and/or secondary overprinting.

\subsection{Amino-acid dating}

In one of the intercalated lignite beds at the bottom part of the section (depth 88 $\mathrm{m})$, two fossils (elephant tooth) were recovered, which allowed the application of the amino-acid method (Oches and William, 1995).

The $\mathrm{D} / \mathrm{L}$ ratios (ratio of $\mathrm{D}$-form to $\mathrm{L}$-form amino-acids) for the most important amino-acids are: D/L-Aspartic Acid $=0.70, \mathrm{D} / \mathrm{L}-$ Glutamic Acid $=0.55, \mathrm{D} / \mathrm{L}-$ Valine $=$ $0.54, \mathrm{D} / \mathrm{L}-\mathrm{Phenylalanine}=0.85$, Alloisoleucine/Isoleucine $=0.67$. They reflect the degree of racemization that has occurred in the sample during the entire period since the original formation of the tooth and include the effects of both, age and temperature history of the sample. There are two possible interpretations:

(1) Assuming a slightly elevated post-burial temperature history, effective temperatures were similar to known standard samples in Hungary (for samples that weren't heated due to deep burial), thereby making the tooth possibly around $0.8 \mathrm{Ma} \pm 30 \mathrm{kyr}$ old.

(2) Assuming no significant elevation in temperature, effective temperatures were close to known standard samples in Czech Republic sites, thereby making the tooth considerably older than the B/M boundary, possibly close to $1.0 \mathrm{Ma} \pm 40 \mathrm{kyr}$.

Summarizing from amino-acid dating, the part of the section where the fossil was discovered has an age between 0.8 to $1.0 \mathrm{Ma}$. This is in agreement with the magnetostratigraphic result as the fossil was found within the Jaramillo subchron (0.991.07 Ma (Cande and Kent, 1995).

\section{Palaeoenvironment}

\subsection{Anisotropy of magnetic susceptibility}


Final manuscript of paper published as: Journal of Asian Earth Sciences 30 (2007) 73-81 https://doi.org/10.1016/j.jseaes.2006.07.009

Anisotropy of magnetic susceptibility (AMS) may reflect the depositional regime. More than 230 samples from various depths were measured using 15 directions. The directions of maximum $\left(\kappa_{1}\right)$ and minimum susceptibility axes $\left(\kappa_{3}\right)$ are plotted in Figure. 6. The $\kappa_{3}$ axes which are interpreted to represent the poles to the bedding planes show a clearly better grouping in the bottom part $(20-123 \mathrm{~m})$ of the section than in the upper part $(0-20 \mathrm{~m})$. The lineation of the AMS fabric shown by $\kappa_{1}$ axes has in general NW-SE trend. The AMS fabric therefore is primarily sedimentary ( $\mathrm{k} 3$ corresponding to bedding poles) with possible control of the $\kappa_{1}$ axes by paleocurrents (either from NW or SE) or tectonism ( $\kappa_{1}$ nearly perpendicular to the tectonic compression) (Gautam et al., 2000).

\section{Discussion}

Magnetostratigraphy reveals four polarity changes but only 9 samples represent the oldest polarity zone below $119.5 \mathrm{~m}$, out of which the bottommost 5 samples are consecutive. Further sampling could not be carried out as the formation is unexposed beyond this depth at our sampling area. The calculated rate of deposition during Jaramillo period is $\sim 30 \mathrm{~cm} / \mathrm{kyr}$. Assuming similarity in the sedimentation rate during Jaramillo subchron and below it, the age of the polarity change at $119.5 \mathrm{~m}$ depth would become $1.07 \mathrm{Ma}+15 \mathrm{~m} / .30 \mathrm{~m} / \mathrm{kyr}=\sim 1.12 \mathrm{Ma}$. The observed polarity transition at $119.5 \mathrm{~m}$ is likely to represent the normal polarity Cobb Mountain event corresponding to ca. 1.1 Ma (Mankinen et al., 1978). Alternatively, this transition may represent the upper boundary of the Olduvai subchron (1.79 Ma). In the latter case, however, the deposition rate of the reverse polarity interval between $102.5 \mathrm{~m}$ and $119.5 \mathrm{~m}$ would have been extremely low $(15 \mathrm{~m} /(1.79-1.07 \mathrm{Ma}))=2.08 \mathrm{~cm} / \mathrm{kyr})$. Because of the similarity in lithology from $77.5 \mathrm{~m}$ to $119.5 \mathrm{~m}$, strongly varying deposition rates are unlikely and therefore the preferred interpretation for the lowest normal polarity zone is the Cobb Mountain event.

Polarity stratigraphy and amino-acid dating result in a well-constrained age model for the sampled section. Fine-grained beds are predominant in the lower part of the section (below 67.5m), demonstrating a relatively calm sedimentary environment. Also, the lithology of drill wells of Sakai (2001), Sakai et al., (2002) show mostly fine grained sediments during this period.

AMS shows that the maximum susceptibility axis is mainly NW-SE in almost in all parts of the section, consistent with the sediment flow from NW of the lake $\left(\kappa_{1}\right.$ parallel flow for calm flow regime). This strongly suggests that the lake regained its usual 
Final manuscript of paper published as: Journal of Asian Earth Sciences 30 (2007) 73-81 https://doi.org/10.1016/j.jseaes.2006.07.009

sedimentation behaviour after sudden deposition of gravel beds (mainly from the nearby southern side of the lake). In the lower part $\kappa_{3}$ directions are deviating slightly $\left(\sim 10^{\circ}\right)$ from the vertical direction, which can be related to northward tilting of about $5^{\circ}$ to $10^{\circ}$ after deposition. The directions of the AMS of the topmost part of the section is more scattered which can be explained due to disturbance caused by tectonism related to uplift of the Mahabharat Lekh after deposition of these valley sediments. This tectonic disturbance might have started already earlier as $\kappa_{3}$ axes are getting more scattered above ca. $80 \mathrm{~m}$ (expressed by larger scatter of $\kappa_{3}$ declinations) (Fig. $6 \mathrm{a}, \mathrm{b}$ ).

\section{Conclusions}

Magnetic polarity data for the $125 \mathrm{~m}$ thick section of fluviolacustrine deposits in Lokundol in the southern part of the Kathmandu Valley and amino-acid date from a single horizon in it suggest the most plausible age of $\sim 0.75-1.1 \mathrm{Ma}$.

AMS data are consistent with predominantly sedimentary depositional fabric throughout the section as shown by subvertical minimum axes corresponding to the bedding planes. The maximum AMS axes are mainly NW-SE oriented and most probably reflect a paleocurrent direction. In analogy of the AMS data from the Siwalik sections, however, a tectonic origin of these axes, can't be denied.

\section{Acknowledgements}

We thank K. Kodama and two anonymous reviewers for their valuable comments. The study was financed by the German Research Foundation, Germany.

\section{References}

Cande, S.C., Kent, D.V., 1995. Revised calibration of the geomagnetic polarity timescale for the late Cretaceous and Cenozoic. Journal of Geophysical Research 100, 60936095.

Dongol, G.M.S., 1985. Geology of the Kathmandu Xuviatile lacustrine sediments in the light of new vertebrate fossil occurrences. Journal of Nepal Geological Society 4, 4357 (Special issue).

Dongol, G.M.S., 1987. The stratigraphic signiWcance of vertebrate fossils from the Quaternary deposits of the Kathmandu Basin, Nepal. Newsletters in Stratigraphy 18, 21-29. 
Final manuscript of paper published as: Journal of Asian Earth Sciences 30 (2007) 73-81 https://doi.org/10.1016/j.jseaes.2006.07.009

Fujii, R., Sakai, H., 2001. Palaeoclimatic changes during the last 2.5 myr recorded in Kathmandu basin, Central Nepal Himalayas. Journal of Asian Earth Sciences 20, $255-266$.

Gautam, P., Hosoi, A., Regmi K. R., Khadka, D.R., Fujiwara Y., 2000. Magnetic minerals and magnetic properties of the Siwalik Group sediments of the Karnali river section in Nepal. Earth Planets \& Space 52, 337-345.

Hahn, D.G., Manabe, S., 1975. The role of mountains in the South Asian monsoon circulation. Journal of Atmospheric Sciences 32, 1515-1541.

Hu, S., Stephenson, A., Appel E., 2002. A study of gyroremanent magnetisation (GRM) and rotational remanence magnetisation (RRM) carried by greigite from lake sediments. Geophysical Journal International 151, 468-474.

Kent, D.V., 1973. Post-depositional remanent magnetization in deep sea sediment. Nature 246, 32-34.

Mankinen, E. A., Donnelly, J. M., Grommé, C. S., 1978. Geomagnetic polarity event recorded at 1.1 m.y. B.P. on Cobb Mountain, Clear Lake volcanic field, California. Geology 6, 653-656.

Moribayashi, S., Maruo, Y., 1980. Basement topography of the Kathmandu valley, Nepal- An application of gravitational method to the survey of a tectonic basin in the Himalayas. Journal of the Japan Society of Engineering Geology 21-2, 30-37.

Oches, E., William M., 1995. Amino acid geochronology applied to the correlation and dating of central European loess deposits. Quaternary Science Reviews 14, 767-782.

Raymo, M. E., Ruddiman, W. F., 1992. Tectonic forcing of late Cenozoic climate. Nature $359,117-122$.

Sakai, H., 2001. Stratigraphic division and sedimentary facies of the Kathmandu basin sediments. Journal of Nepal Geological Society 25, 19-32.

Sakai, H., Fujii, R., Kuwahara, Y., 2002. Changes in depositional system of the palaeoKathmandu lake caused by uplift of the Nepal Lesser Himalayas. Journal of Asian Earth Sciences 20, 267-276.

Shresta, O.M., Koirala, A., Karmacharya, S.L., Pradhanaga, U.B., Pradhan, R., Karmacharya, R., 1998. Engineering and environmental geology map of Kathmandu valley (1:50,000). Department of Mines and Geology, His Majesty's government of Nepal. 
Final manuscript of paper published as: Journal of Asian Earth Sciences 30 (2007) 73-81 https://doi.org/10.1016/j.jseaes.2006.07.009

Stöcklin, J., Bhattarai, K.D., 1981, Geological map of Kathmandu area and central Mahabharat Range $(1: 25,0000)$. Department of Mines and Geology, His Majesty's government of Nepal.

Verosub, K.L., Banerjee, S.K., 1977. Geomagnetic excursion and their paleomagnetic record, Reviews of Geophysics and Space Physics 15, 145-155.

Yoshida, M., Gautam, P., 1988. Magnetostratigraphy of Plio-Pleistocene lacustrine deposits in the Kathmandu valley central Nepal. Proceedings of Indian National Science Academy 54, 410-417.

Yoshida, M., Igarashi, Y., 1984. Neogene to Quaternary Lacustrine sediments in the Kathmandu Valley, Nepal. Journal of Nepal Geological Society 4, 73-100 (Special issue).

\section{Figure and Table Captions}


Final manuscript of paper published as: Journal of Asian Earth Sciences 30 (2007) 73-81 https://doi.org/10.1016/j.jseaes.2006.07.009
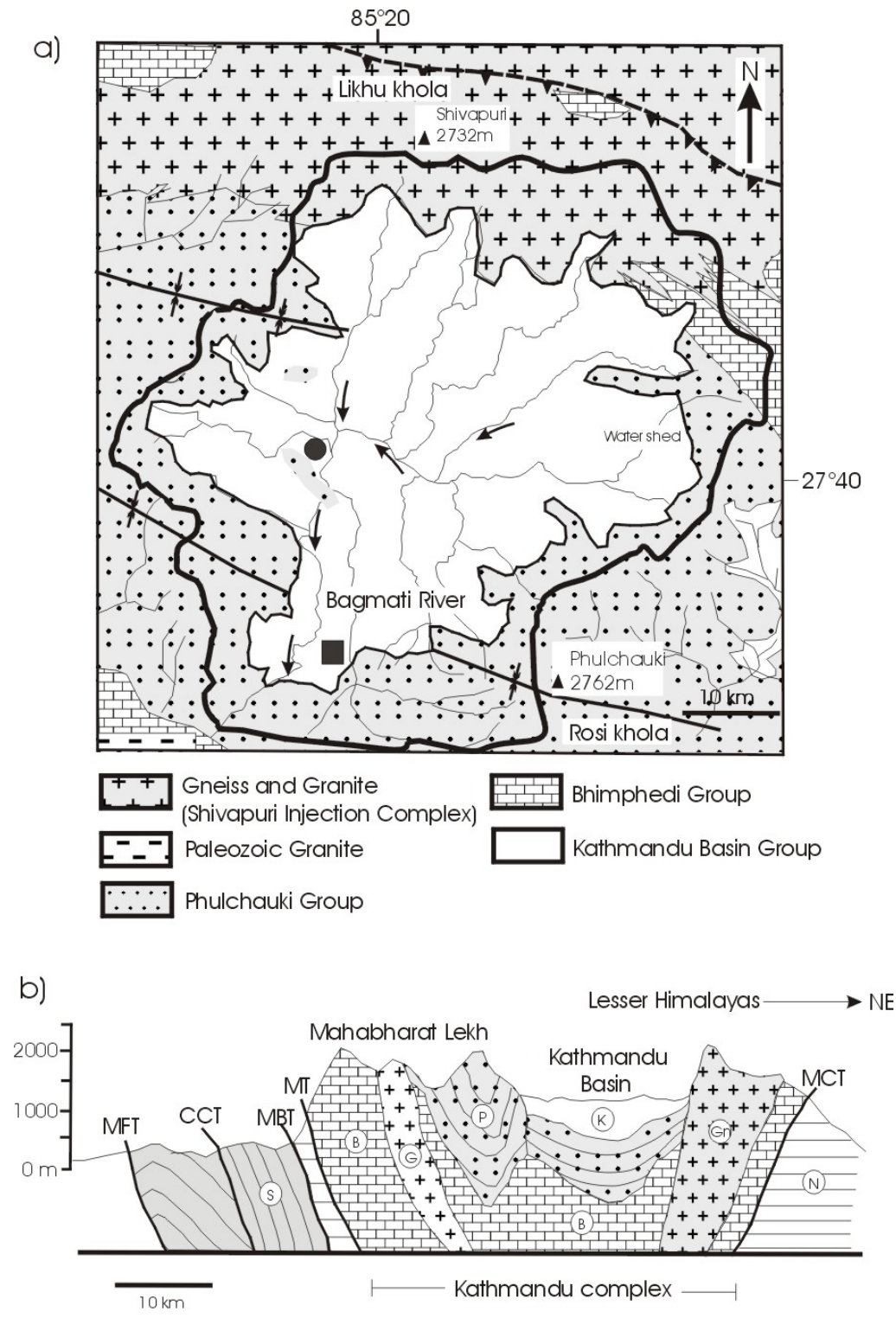

Fig. 1: Simplified map (a) and schematic geological cross-section (b) in the central Nepal Himalayas based on Fujii et. al (2001) and Sakai et al. (2002) (modified after Stöcklin and Bhattarai, 1981). The filled circle and square in the map are locations of the borehole JW3 (Sakai, 2001) and the sampling area (Lukundol village) of this study, respectively. In the cross-section, thrusts are indicated by MFT (Main Frontal Thrust), CCT (Central Churia Thrust), MBT (Main Boundary Thrust), MT (Mahabharat Thrust) and MCT (Main Central Thrust). Rock formations and rocks are indicated by S (Siwalik Group), B (Bhimphedi Group), P (Phulchauki Group), N (Nawakot Complex), K (Kathmandu Complex), G (Granite), and Gn (Gneiss). 
Final manuscript of paper published as: Journal of Asian Earth Sciences 30 (2007) 73-81 https://doi.org/10.1016/j.jseaes.2006.07.009

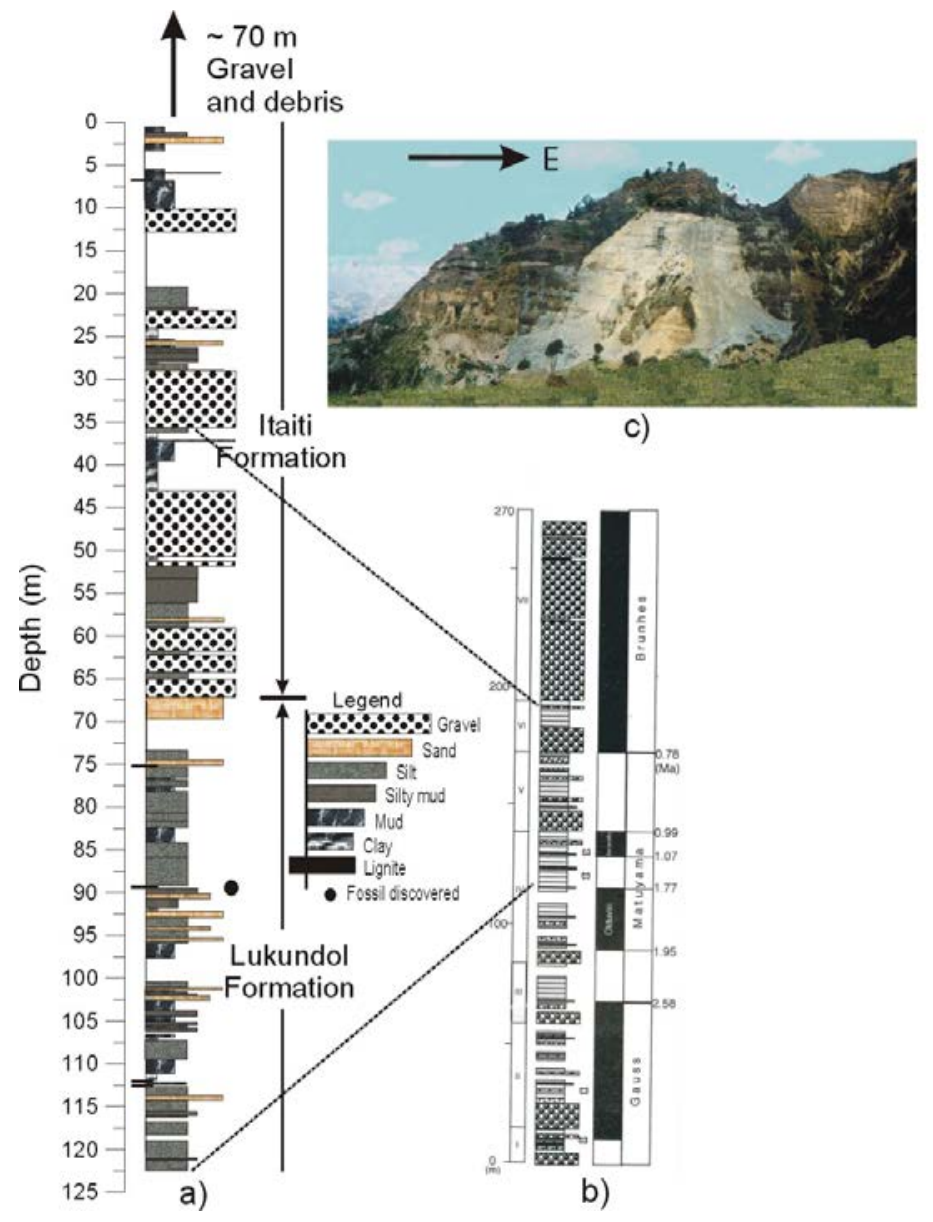

Fig. 2: (a) Exposure of the Lukundol and Itaiti formation at Lukundol village. (b) Detailed lithostratigraphy of the sampled section (Lukundol formation) and its approximate correlation with the litholog of Yoshida and Gautam (1988). 
Final manuscript of paper published as: Journal of Asian Earth Sciences 30 (2007) 73-81 https://doi.org/10.1016/j.jseaes.2006.07.009
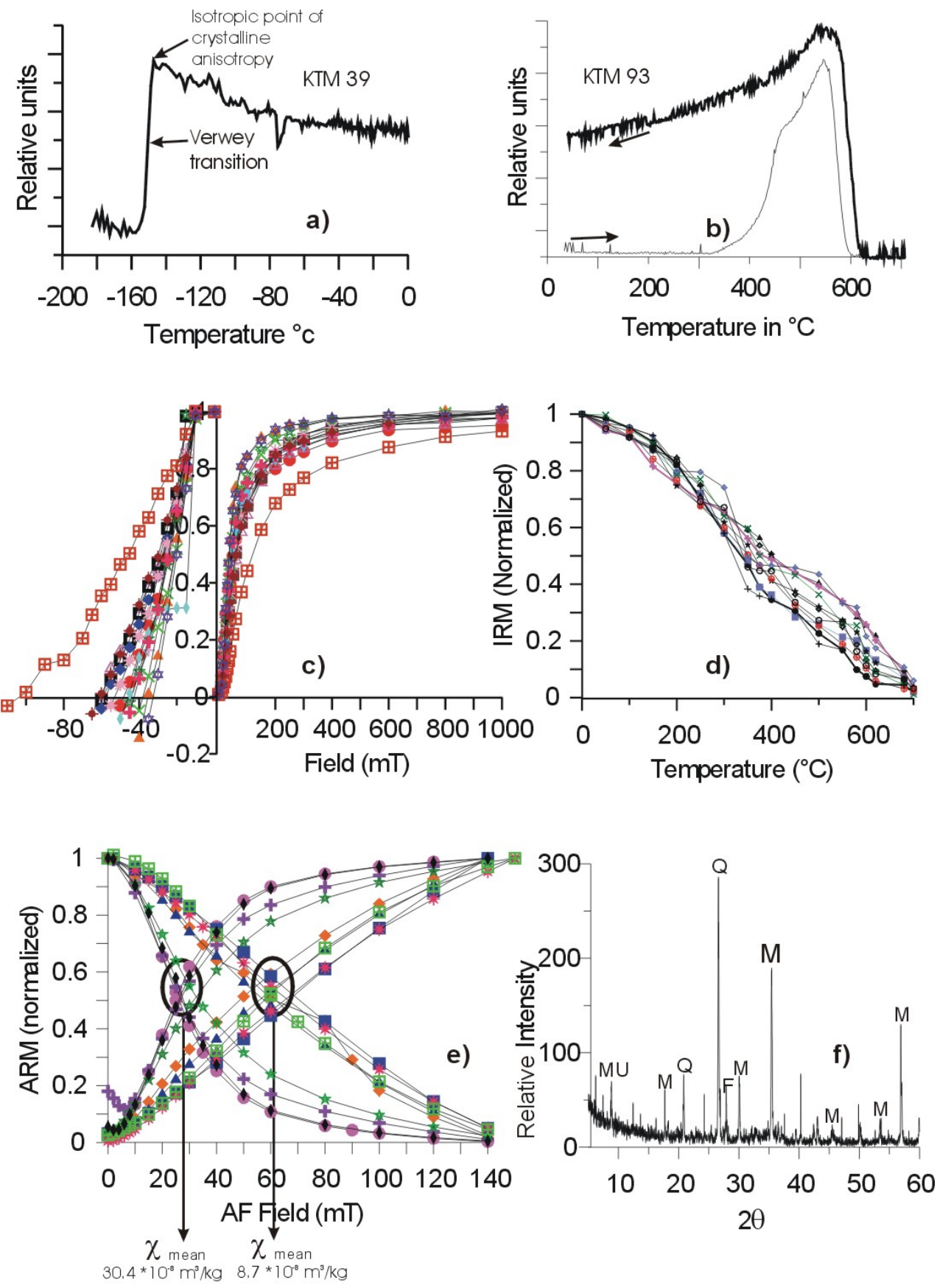

Fig. 3

Fig. 3: Results of measurements of the thermal variation of magnetic susceptibility in low temperature range (a) and high temperature range (b), in which thin and thick lines represent heating and cooling curves, respectively. Samples KTM39 and KTM93 were taken from depth levels of $117.8 \mathrm{~m}$ and $112.6 \mathrm{~m}$, respectively. (c) Stepwise IRM acquisition and backfield demagnetization curves. (d) SIRM thermal demagnetization curve. (e) Plots of ARM acquisition, with an AF of $100 \mathrm{mT}$ and biasing field of $0.1 \mathrm{mT}$ DC field, versus its AF demagnetization; Regions of intersection shown represent the coercivities of two components with contrasting susceptibility. (f) Results of X-Ray diffraction on a magnetic extract, showing M- magnetite, MU- muscovite, F- feldspar, and Q- quartz. 
Final manuscript of paper published as: Journal of Asian Earth Sciences 30 (2007) 73-81 https://doi.org/10.1016/j.jseaes.2006.07.009

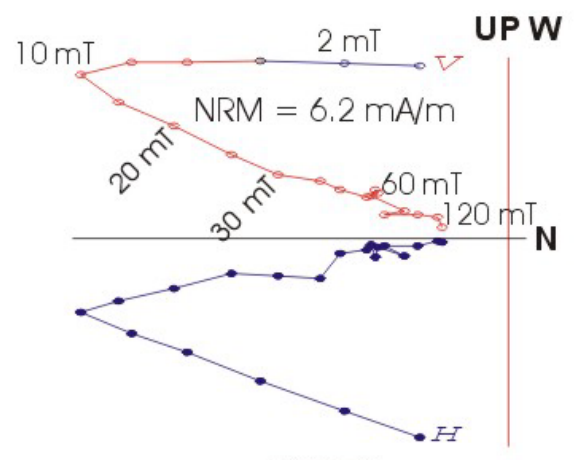

IN SITU

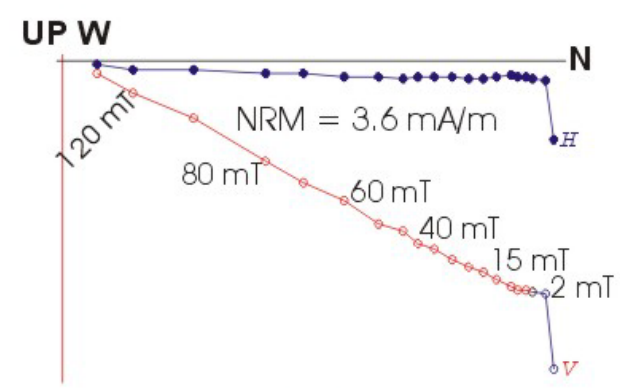

IN SITU

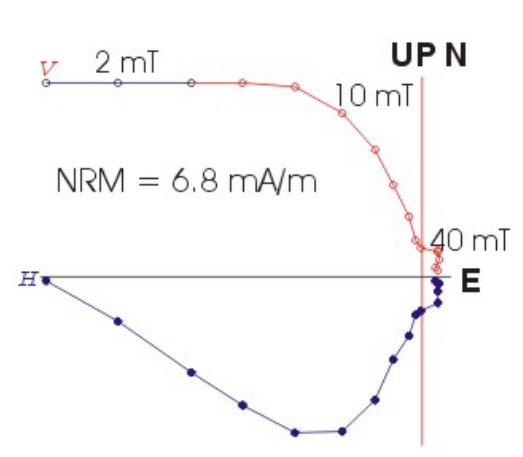

IN SITU

- Horizontal projection

- Vertical projection

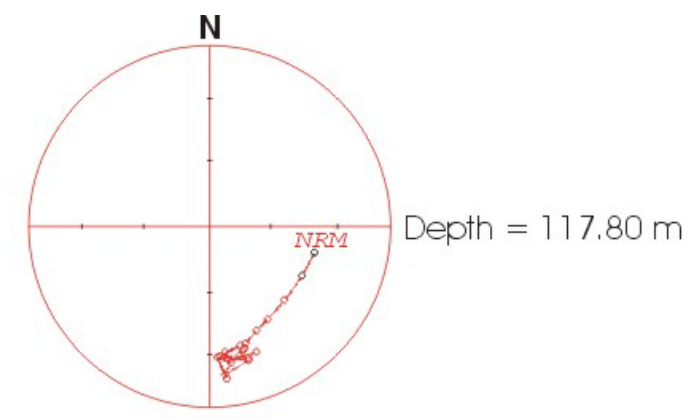

IN SITU

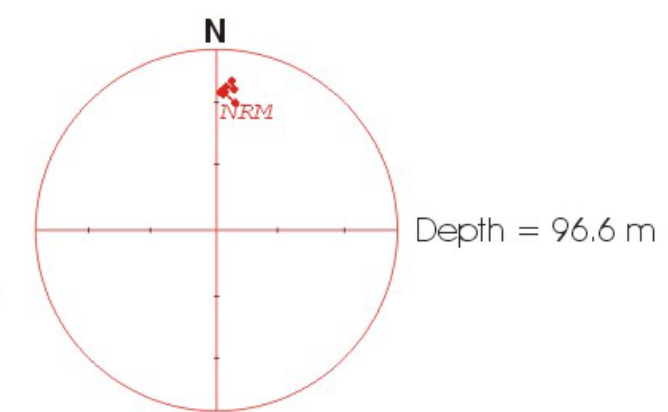

IN SITU

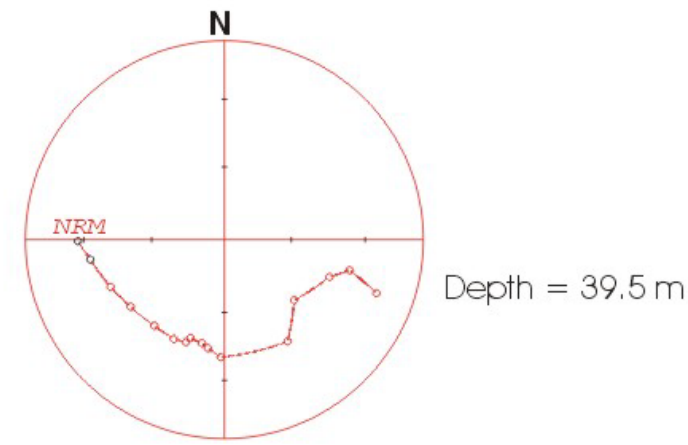

IN SITU

- I > 0 (downward)

I $<0$ (upward)

Fig. 4: Results of AF demagnetisation for representative samples at different depths : Orthogonal vector plots (left) and equal area projection (right). 
Final manuscript of paper published as: Journal of Asian Earth Sciences 30 (2007) 73-81 https://doi.org/10.1016/j.jseaes.2006.07.009

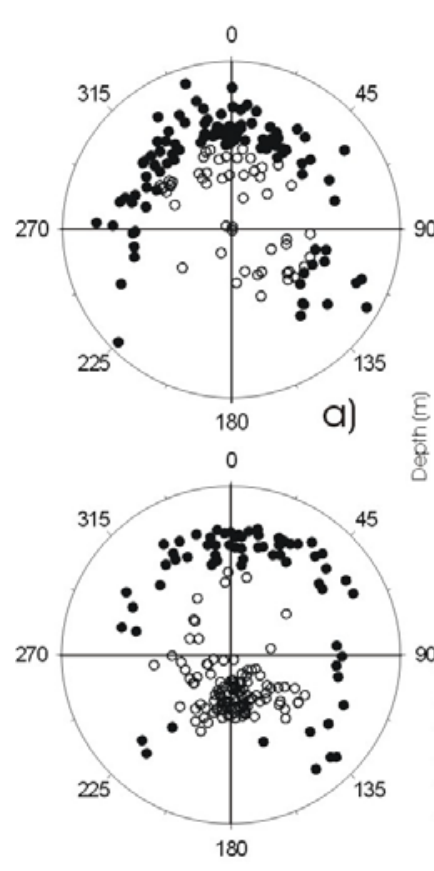

b)

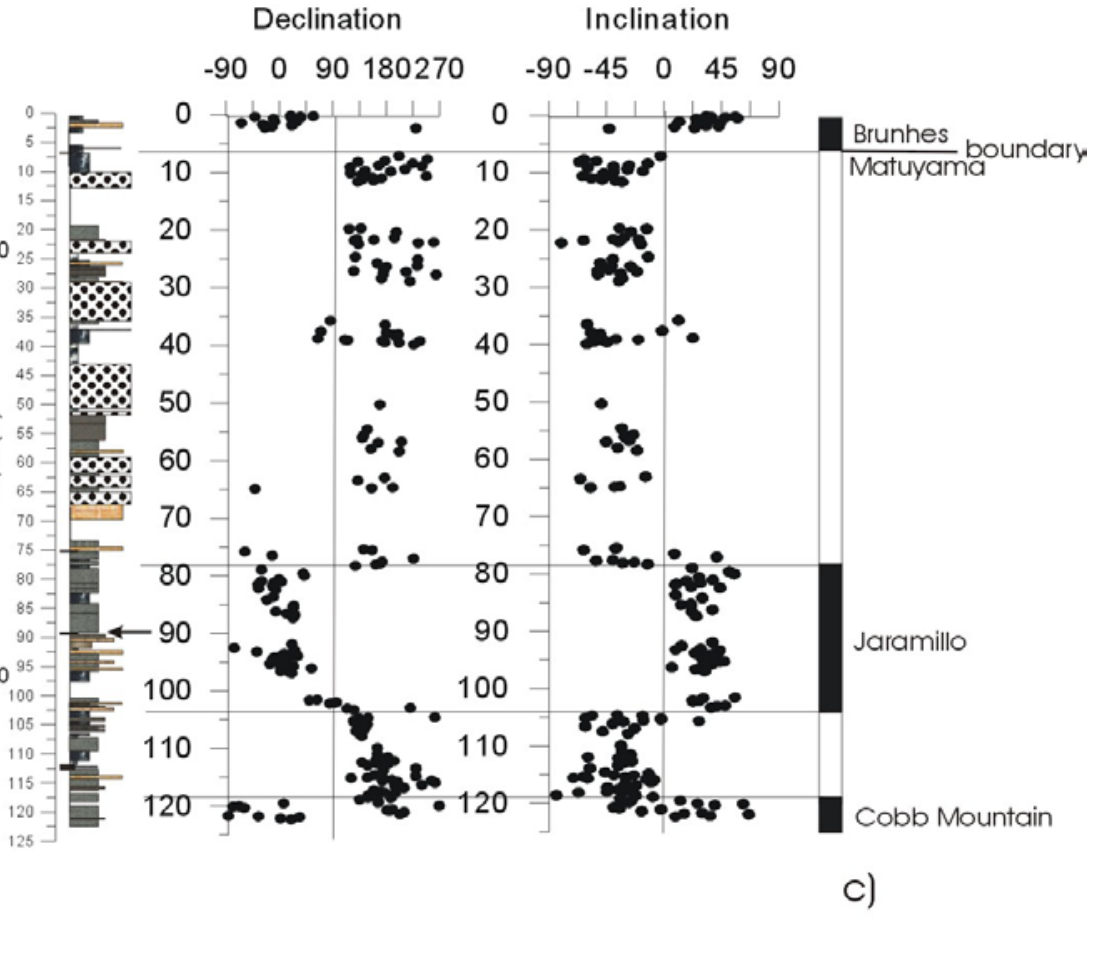

Fig. 5: (a) Equal area projection of the directions of the first (lower coercive) magnetic component removed generally within alternating fields of $2 \mathrm{mT}-15 \mathrm{mT}$ corresponding to viscous remanence. (b) The directions of the second (higher coercive) magnetic component designated as ChRM and isolated above $20 \mathrm{mT}$. (c) Declination and inclination of ChRM versus depth with litholog and geomagnetic polarity intervals. The arrow indicates the horizon yielding fossil teeth. 
Final manuscript of paper published as: Journal of Asian Earth Sciences 30 (2007) 73-81 https://doi.org/10.1016/j.jseaes.2006.07.009
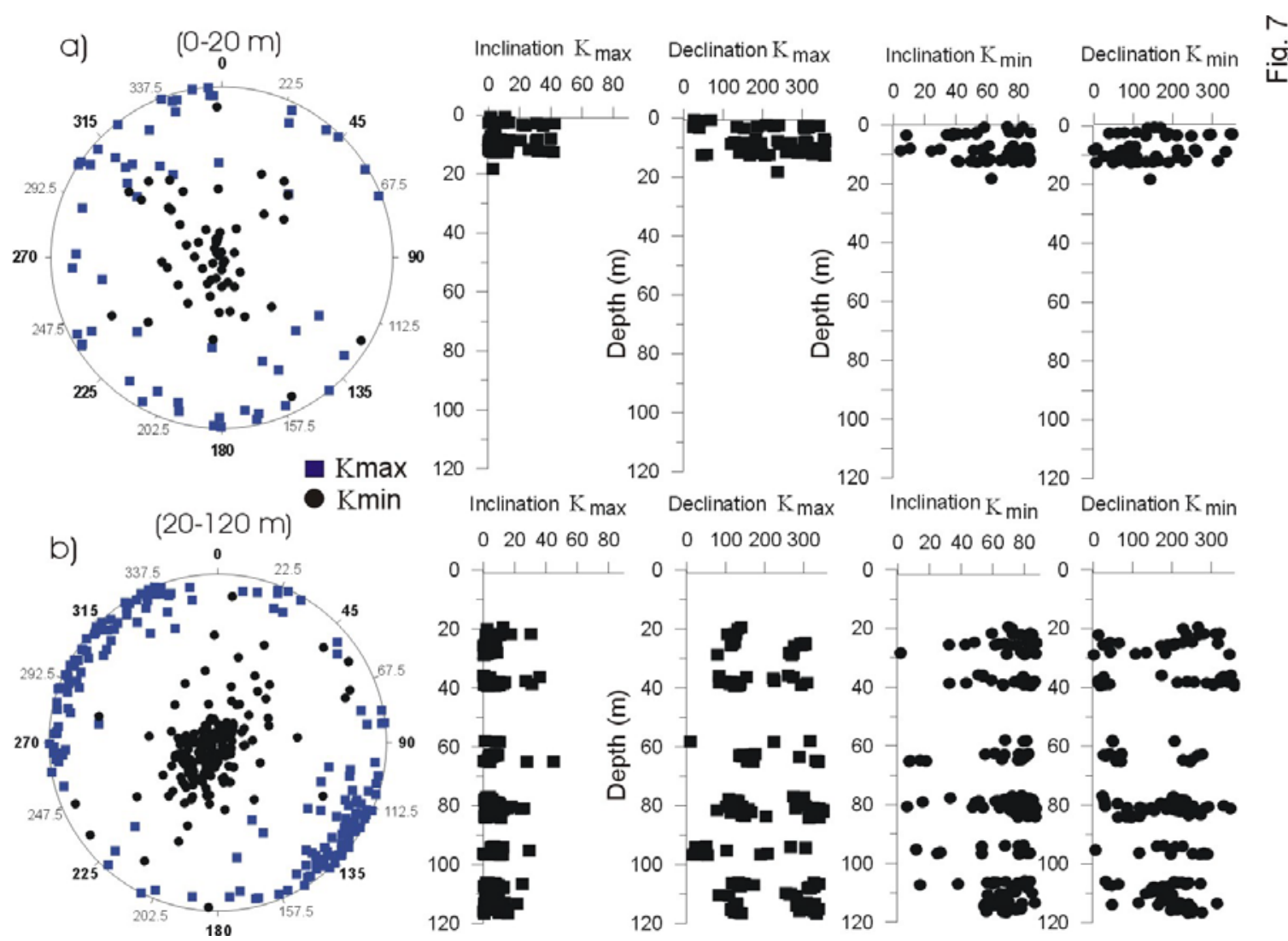

Fig. 6: Results of anisotropy of susceptibility (AMS) from (a) 0-20 m and (b) 20-123 m and variation of $\kappa_{\max }$ and $\kappa_{\min }$ directions along the section.

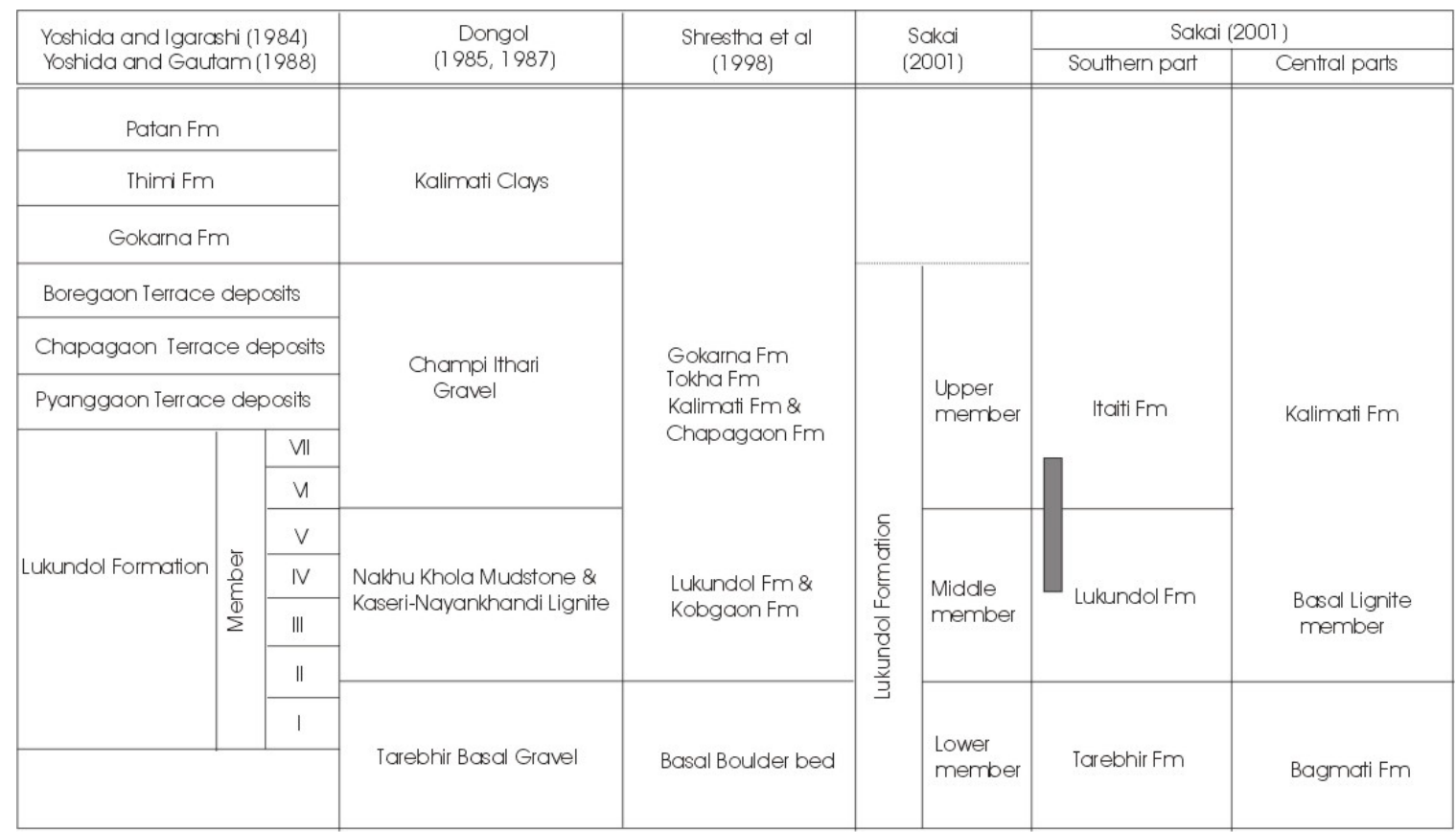

Table 1: Stratigraphic correlation of the Kathmandu basin sediments (mainly after Sakai, 2001). The black bar shows the stratigraphic position of the Lukundol section sampled in this study. 